\title{
PRZEWALSKI'S HORSE REINTRODUCTION IN THE STATE NATURAL RESERVE «ORENBURGSKY»: THE FIRST RESULTS
}

(C) 2019

Tyurin Alexandr Nikolayevich, candidate of geographical sciences, associate professor of Geography and Methods of Geography Teaching Department Orenburg State Pedagogical University (Orenburg, Russian Federation)

Abstract. This paper presents a chronology of the main events taking place within the framework of the program to resettle Przhewalsky's horses to the territory inhabited by their close relatives, the tarpans, to create a new and sustainable population of these animals. The Przewalski's horse population under natural conditions of the State Natural Reserve «Orenburgsky» will allow having a reserve of healthy, well-developed animals as a guarantee of keeping the species clean for a very long period of time. By the end of the $19^{\text {th }}$ century, not a single Przewalski's wild horse remained in its natural habitat. The paper discusses a gradual reintroduction of Przewalski's horse and presents the first results, taken from open sources, on the restoration of the wild horse population in the Orenburg Region. The first results allow you to look to the future with confidence. 5 healthy foals have already been born in the reserve; PA scientists are optimistic about the spring of 2019 and hope that the stock of wild horses will continue to grow. The Przewalski's horse reintroduction program enjoys a personal support of the Orenburg Region Governor and is among the key projects for the protection of wild animals, personally supervised by the President of the Russian Federation.

Keywords: Przewalski's horse; wild horse; harem group of animals; endangered species; Orenburg Region; State Natural Reserve «Orenburgsky»; cluster reserve; Pre-Ural steppe; «Orenburg Tarpania»; historical area; reserved mode; population; acclimatization.

УДК 576.895.42

DOI 10.24411/2309-4370-2019-11121

Статья поступила в редакцию 25.12.2018

\section{ОЦЕНКА УСТОЙЧИВОСТИ СООБЩЕСТВ ЭКТОПАРАЗИТОВ РУКОКРЫЛЫХ С ПОМОЩЬЮ МЕТОДА ГЛАВНЫХ КОМПОНЕНТ (РСА)}

(C) 2019

Фадеева Галина Анатольевна, кандидат биологических наук, доцент кафедры ботаники и зоологии

Борякова Елена Евгеньевна, кандидат биологических наук, доцент кафедры ботаники и зоологии Национальный исследовательский Нижегородский государственный университет им. Н.И. Лобачевского (2. Нижний Новгород, Российская Федерация)

Аннотация. В пещерах естественного происхождения (юг Нижегородской области) проведены исследования сообществ эктопаразитов шести видов рукокрылых. С помощью метода главных компонент (РСА) оценена устойчивость сообществ эктопаразитов рукокрылых. Поскольку пещеру и ее обитателей можно рассматривать как микробиотоп, то очевидно, что в нем складываются специфические отношения между обитателями. Особые условия обитания опосредованно влияют на складывающиеся там паразитарные системы, которые характеризуются определенной устойчивостью. Предварительно при помощи критерия МаннаУитни оценивалось различие между выборками животных из разных местообитаний. Методы непараметрической статистики не обнаружили достоверных различий по хозяевам, годам и биотопам, и колонию рукокрылых и их эктопаразитов можно оценивать как единую сложно организованную систему, длительно существующую в пространстве и времени. Из всех возможных факторов среды на системы оказывают существенное влияние четыре, вклад первых двух равен 65\% дисперсии (видовая специфичность паразита к хозяину и фактор присутствия видов-доминантов). В сообществе эктопаразитов рукокрылых установились такие взаимосвязи, которые обусловливают успешное существование всех видов без выраженной конкуренции. Каждый вид имеет свою позицию в факторном пространстве. В сообществах эктопаразитов рукокрылых встречаются виды, которые связаны высокой корреляционной зависимостью только с одним фактором (Spinturnix acuminatus, Sp. plecotinus, Leptotrombidium russicum), но обнаруживаются и виды, которые демонстрируют как умеренно-положительные, так и умеренно-отрицательные корреляционные зависимости не с одним фактором, а с несколькими. Например, Spinturnix myoti, Sp. kolenatii, Macronyssus heteromorphus и др. Неодинаковое воздействие среды на паразитарные системы, формирующиеся в пещерах естественного происхождения, обеспечивает устойчивость сообществ эктопаразитов рукокрылых в целом.

Ключевые слова: паразитарная система; рукокрылые; эктопаразиты рукокрылых; карстовые пещеры; Нижегородская область; Среднее Поволжье; гамазовые клещи; спинтурнициды; никтерибеиды; метод главных компонент (РСА); устойчивость сообществ; сообщества паразитов; специфичность паразитов к хозяевам.

\section{Введение}

Паразитарные системы - это саморегулирующиеся экологические системы, в которых отношения между партнерами находятся в состоянии подвижного равновесия. Паразиты могут регулировать плотность своих популяций с помощью механизмов с обратной связью, что приводит к формированию Самарский научный вестник. 2019. Т. 8, № 1 (26) устойчивых, хотя и динамичных паразитарных систем. Устойчивость в пределах системы «паразитхозяин» может значительно варьировать $[1 ; 2$, с. 350 ; 3-5]. Одним из механизмов регуляции численности популяций паразитов является агрегированный характер распределения, подчиняющийся модели отрицательного биномиального распределения [5; 6; 7, 
с. $34 ; 4 ; 8$, с. 96]. В состав паразитарной системы входят, как минимум, две популяционные системы - паразита и хозяина. Реально такая ситуация, однако, наблюдается довольно редко - в случае моноксенного жизненного цикла паразита и строгой его специфичности. Как правило, популяционных систем - элементов паразитарной системы - оказывается больше: паразиты могут использовать несколько популяций разных видов хозяев даже на одной стадии жизненного цикла (параксенные хозяева). Естественно, расширяется круг взаимодействующих популяций в случае еди-, три- и т.д. - ксенных циклов [2; 9, с. 330].

Многочисленные исследования, касающиеся природных популяций паразитов, показывают высокую степень системной целостности паразитарных систем [10, с. 252]. Во многих случаях удается выявить наличие регуляторных механизмов, работающих по принципу обратной связи $[1 ; 11]$; кроме того, взаимодействие особей как элементов таких систем отличается высокой степенью сложности и интегрированности: все больше данных появляется о важности молекулярно-генетического уровня их взаимодействий [12].

Сложные взаимоотношения паразита и хозяина возникают в тех случаях, когда паразиты не проявляют узкой специфичности в выборе хозяев и их популяции поддерживаются несколькими видами хозяев. Такая картина широко распространена среди клещей, например эктопаразитов мелких млекопитающих $[13 ; 14 ; 15$, с. 187; 16, с. 122]. Ю.С. Балашов $[17 ; 15 ; 18-20]$ считает, что стабилизация паразитарных систем клещей птиц и млекопитающих основана не только на обратной связи, но и на межвидовой и внутривидовой конкуренции, причем внутривидовая конкуренция протекает наиболее остро.

Взаимодействие видов в сообществах паразитов, поселяющихся на потенциальных хозяевах, объяснить достаточно сложно, так как на системы оказывают воздействие множество различных факторов как абиотических, так и биотических. Еще более сложно объяснить взаимодействие паразитов в сообществах наземных позвоночных, имеющих сходную фауну эктопаразитов. Рукокрылые и их эктопаразиты могут служить прекрасным объектом для понимания устойчивости паразитарных систем и сообществ эктопаразитов, населяющих смешанные колонии этих животных. Они характеризуются специфичной фауной эктопаразитов и практически не контактируют с другими видами млекопитающих.

\section{Материал и методы исследования}

Сборы эктопаразитов осуществлялись в летний период 2004 и 2005 гг. в двух пещерах - Студенческая и Теплая (Ичалковский бор) с 6 видов рукокрылых (прудовой, усатой, водяной ночниц, ночницы Брандта, северного кожанка, бурого ушана). Отлов рукокрылых проводился с использованием паутинных сетей из нейлоновых нитей, а также вручную. Пойманных летучих мышей помещали в мешки из ткани, сразу же проводилось их обследование: определение вида, пола и прижизненный сбор эктопаразитов.

Собранных эктопаразитов фиксировали 70\% этиловым спиртом. Членистоногие заливались в жидкость Фора-Берлезе. Определение видовой принадлежности собранных паразитов, основную численность которых представляют клещи, проводилось по М.К. Станюкович [21] и Л.М. Пинчук [22; 23], Н.И. Кудряшовой [24], определитель насекомых Ев- ропейской части СССР [25]. Общее число клещей составило 2397 экземпляров, 82 экземпляра паразитических мух, 53 блохи, 1 клоп.

Полученные данные обрабатывались средствами пакета Statistica 6.0. Для сравнения выборок использован однофакторный анализ по Краскелу-Уоллису, попарное сравнение производилось по методу Ньюмана-Кейлса. Для выделения сходных групп применялся метод Principal Components Analysis (PCA), являющийся весьма эффективным при обработке экологических данных [26].

\section{Результаты и их обсуждение}

В 2004-2005 гг. на территории памятника природы «Ичалковский бор» (Нижегородская область) проведены исследования эктопаразитов 6 видов рукокрылых: водяной ночницы, ночницы Брандта, усатой ночницы, прудовой ночницы, северного кожанка и бурого (обыкновенного) ушана. На летучих мышах обнаружено 18 видов членистоногих, из них доминируют гамазовые клещи (10 видов) и клещи краснотелки (2 вида) [27, с. 123]. На всех видах рукокрылых преобладали гамазовые клещи: Spinturnix acuminatus, Sp. kolenatii, Sp. myoti, Sp. mystacinus, Sp. plecotinus, Steatonyssus spinosus, St. periblepharus, Macronyssus flavus, M. heteromorphus. Краснотелковые клещи Leptotrombidium russicum и Myotrombicula sp. отмечены впервые для Средней полосы России. Из насекомых встречены мухи из семейства Nycteribiidae (Nycteribia kolenatii, Penicillidia monoceros) и блохи из ceмейства Ischnopsyllidae (Ischnopsyllus obscurus, Isch. hexactenus). Ixodes vespertilionis, Ornithonyssus pipistrelli и Cimex cf. pipistrelli найдены в единичных экземплярах.

В фауне эктопаразитов рукокрылых пещер Ичалковского бора выделяются виды-доминанты, которые могут влиять на численность других видов. Это Spinturnix acuminatus, Leptotrombidium russicum, Sp. plecotinus, Sp. kolenatii. В связи с этим нами ранее был посчитан индекс Бергера-Паркера, по величине которого можно косвенно судить о наличии или отсутствии конкурентных отношений в сообществах паразитов. Низкие значения индекса Бергера-Паркера $(0,2-0,4)$ указывают на отсутствие ярко выраженной конкуренции между видами, что свидетельствует об устойчивости паразитарных сообществ, сложившихся на рукокрылых в смешанных колониях и в естественных местообитаниях [27, с. 124].

Поскольку пещеру и ее обитателей можно рассматривать как микробиотоп, то совершенно очевидно, что в нем складываются специфические отношения между обитателями. Особые условия обитания опосредованно должны влиять и на эктопаразитов.

Однако сравнение выборок эктопаразитов рукокрылых обеих пещер - Студенческая и Теплая - с применением непараметрической статистики по Краскелу-Уоллису и критерия Ньюмана-Кейлса не выявило достоверных различий $(\mathrm{p}>0,05)$ - как по годам, так и по биотопам. Это подтверждает наше предположение, что сообщества эктопаразитов рукокрылых характеризуются определенной стабильностью. Поскольку методы непараметрической статистики не обнаружили достоверных различий по хозяевам, годам и биотопам, для последующего анализа мы рассматривали смешанную колонию рукокрылых как единое целое, существующее в пространстве и времени. 
Исходя из этого, был проведен анализ сообществ эктопаразитов обследованных видов летучих мышей методом главных компонент с целью выявления факторов, влияющих на состав эктопаразитофауны и численность и распределение их в смешанных колониях рукокрылых. Результаты анализа приведены на рис. 1 и 2.

Пространственная проекция видов клещей и насекомых в зависимости от главных факторов, выявленных методом РСА, подтверждает наше предпо- ложение, что в сообществе эктопаразитов рукокрылых установились такие взаимосвязи, которые обусловливают успешное существование всех видов без выраженной конкуренции. Так, на рис. 1 и 2 видно, что каждый вид имеет свою позицию в факторном пространстве. Их пространственное размещение указывает на то, что факторы, влияющие на системы, в процессе их эволюции не только сбалансировали численности популяций паразитов, но и каждый вид имеет свою нишу.

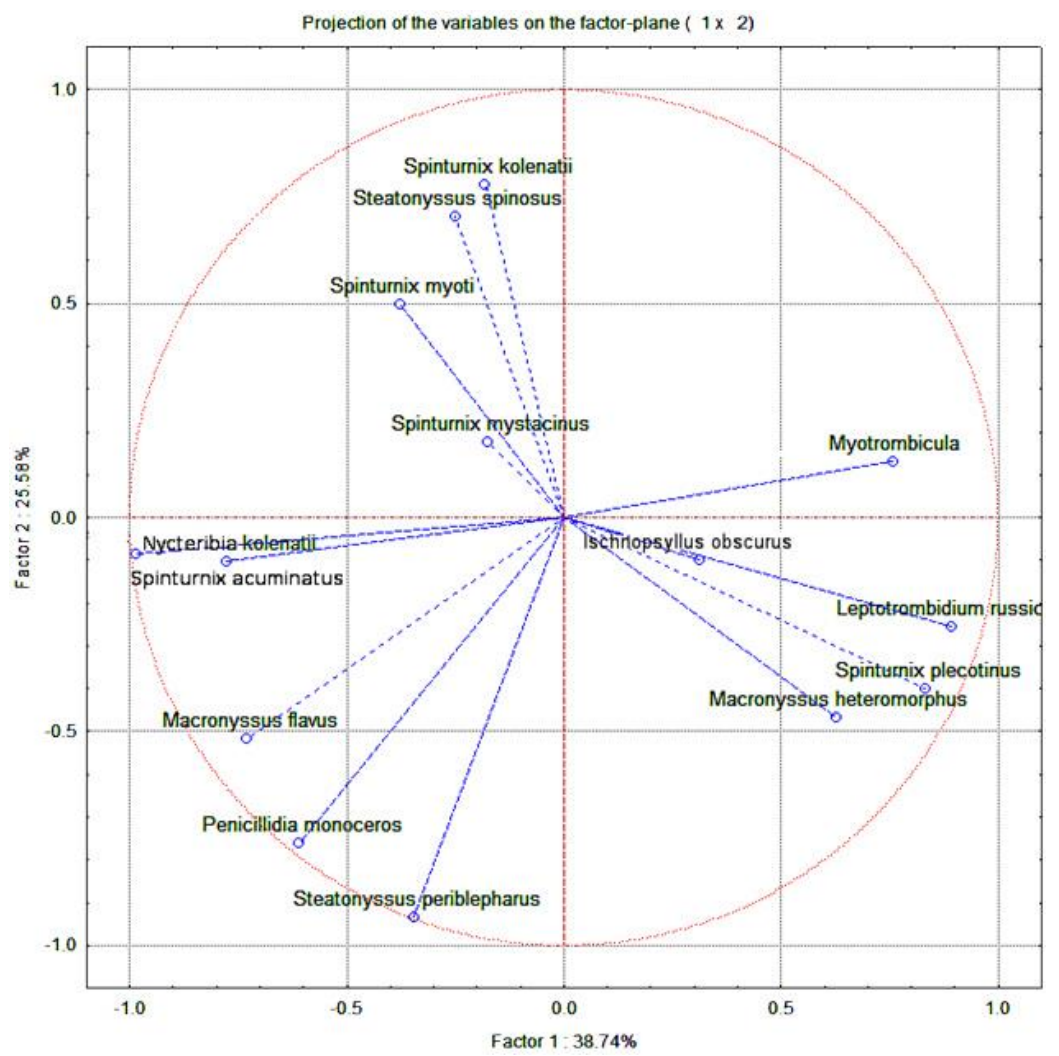

Рисунок 1 - Проекция видов паразитов в факторном пространстве в зависимости от факторов 1 и 2

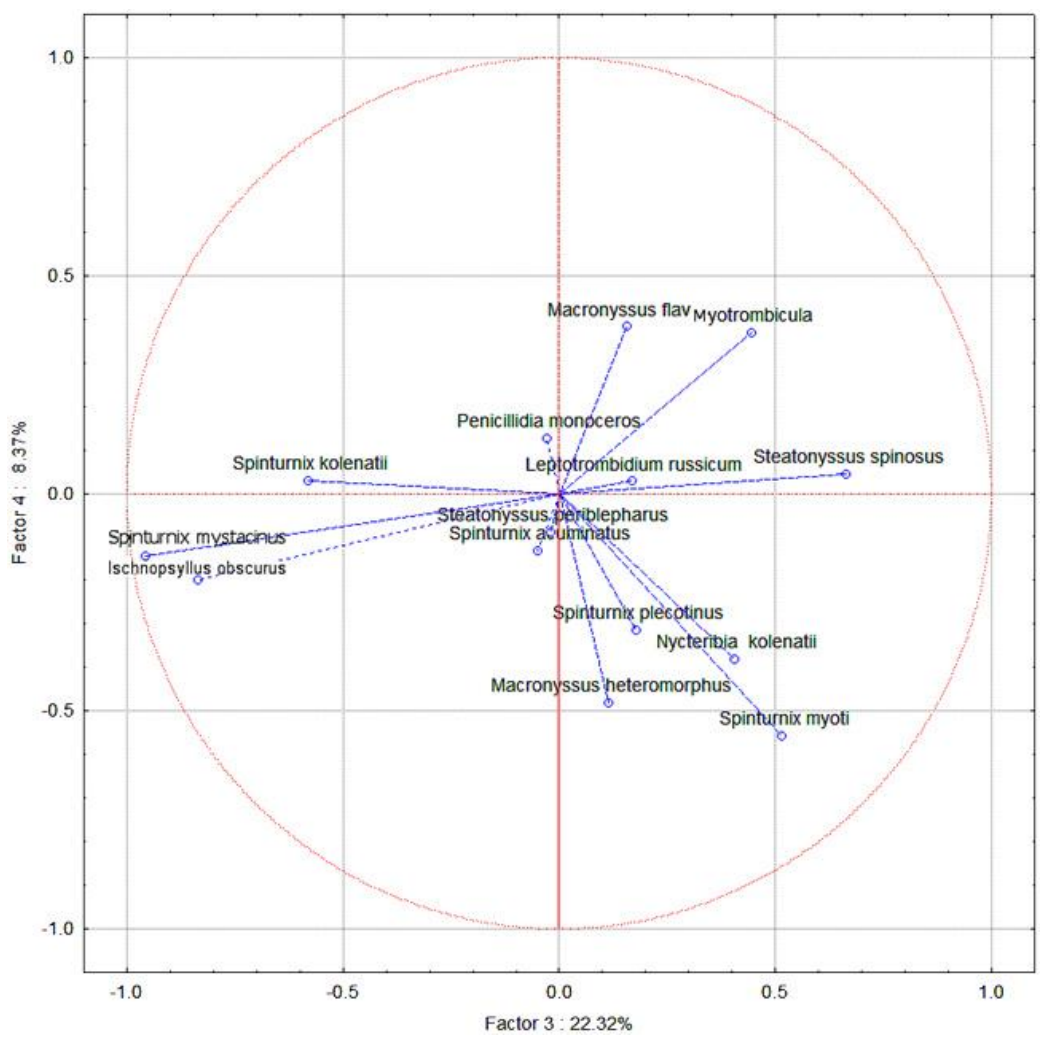

Рисунок 2 - Проекция видов паразитов в факторном пространстве в зависимости от факторов 3 и 4 
По результатам РСА выяснено, что на паразитарные сообщества оказывают влияние четыре главных фактора. Факторная нагрузка 1 -го равна $38,7 \%$, второго $-25,6 \%$, третьего - 22,3\%. Четвертый фактор имеет невысокие показатели $(8,4 \%)$, но игнорировать его невозможно, так как некоторые виды эктопаразитов зависят и от него. Обращает на себя внимание и то, что эктопаразиты по отношению к четырем факторам объединились в 6 групп, при этом они разнесены по этим группам, и - входя в одну, в другой отсутствуют (табл. 1). Каждый вид сообщества в достаточной степени сопряжен с одним из факторов.

Так, по отношению к первому фактору виды $S p$. plecotinus $(+0,83)$ и L. russicum $(+0,89)$ демонстрируют высокую положительную связь. Из особенностей биологии этих видов ясно, что они проявляют высокую специфичность к северному кожанку и бурому ушану. В другую группу объединились Sp. acuminatus $(-0,99)$, Macronyssus flavus $(-0,73)$, Nycteribia kolenatii $(-0,78)$. Эти виды чаще всего встречаются на ночницах и, по-видимому, не проявляют строгой специфичности в выборе хозяев. Итак, из вышеизложенного можно сделать вывод, что первый фактор - это видовая специфичность паразита к хозяину.

Таблица 1 - Результаты РСА-анализа сообществ эктопаразитов рукокрылых

\begin{tabular}{|l|c|r|r|c|}
\hline \multicolumn{1}{|c|}{ Переменная } & $\begin{array}{c}\text { Фактор } \\
1\end{array}$ & $\begin{array}{c}\text { Фактор } \\
2\end{array}$ & $\begin{array}{c}\text { Фактор } \\
3\end{array}$ & $\begin{array}{c}\text { Фактор } \\
4\end{array}$ \\
\hline $\begin{array}{l}\text { Spinturnix } \\
\text { acuminatus }\end{array}$ & $-0,986$ & $-0,083$ & $-0,050$ & $-0,132$ \\
\hline Spinturnix myoti & $-0,379$ & 0,500 & 0,515 & $-0,556$ \\
\hline $\begin{array}{l}\text { Spinturnix } \\
\text { plecotinus }\end{array}$ & 0,832 & $-0,400$ & 0,179 & $-0,313$ \\
\hline $\begin{array}{l}\text { Spinturnix } \\
\text { mystacinus }\end{array}$ & $-0,175$ & 0,176 & $-0,957$ & $-0,145$ \\
\hline $\begin{array}{l}\text { Spinturnix } \\
\text { kolenatii }\end{array}$ & $-0,182$ & 0,779 & $-0,582$ & 0,030 \\
\hline $\begin{array}{l}\text { Macronyssus } \\
\text { heteromorphus }\end{array}$ & 0,627 & $-0,466$ & 0,114 & $-0,481$ \\
\hline $\begin{array}{l}\text { Macronyssus } \\
\text { flavus }\end{array}$ & $-0,730$ & $-0,516$ & 0,156 & 0,383 \\
\hline $\begin{array}{l}\text { Steatonyssus } \\
\text { periblepharus }\end{array}$ & $-0,346$ & $-0,933$ & $-0,019$ & $-0,088$ \\
\hline $\begin{array}{l}\text { Steatonyssus } \\
\text { spinosus }\end{array}$ & $-0,250$ & 0,703 & 0,664 & 0,045 \\
\hline $\begin{array}{l}\text { Leptotrombidium } \\
\text { russicum }\end{array}$ & 0,891 & $-0,255$ & 0,168 & 0,028 \\
\hline Myotrombicula & 0,756 & 0,131 & 0,444 & 0,370 \\
\hline $\begin{array}{l}\text { Nycteribia } \\
\text { kolenatii }\end{array}$ & $-0,779$ & $-0,101$ & 0,406 & $-0,380$ \\
\hline $\begin{array}{l}\text { Penicillidia } \\
\text { monoceros }\end{array}$ & $-0,610$ & $-0,759$ & $-0,029$ & 0,126 \\
\hline $\begin{array}{l}\text { Ischnopsyllus } \\
\text { obscurus }\end{array}$ & 0,312 & $-0,100$ & $-0,837$ & $-0,199$ \\
\hline
\end{tabular}

По отношению ко второму фактору в группу с высокой отрицательной связью объединились Steatonyssus periblepharus $(-0,93)$, Penicillidia sp. $(-0,76)$, a с высокой положительной - Sp. myoti $(+0,50), S p$. kolenatii $(+0,78)$, St. spinosus $(+0,70)$. Численности популяций этих паразитов невелики, поэтому можно предположить, что данные виды не выдерживают конкуренции с видами-доминантами. Таким образом, второй фактор может быть интерпретирован как фактор присутствия видов-доминантов, более пластич- ных к условиям обитания, которые удерживают численности популяций этих видов. Спинтурнициды занимают сходные экологические ниши, Sp. acuminatus оказался более приспособленным в выборе хозяев.

Поскольку знания биологии эктопаразитов рукокрылых на настоящий момент еще недостаточны, связь некоторых видов с третьим фактором интерпретировать достаточно сложно. Sp. kolenatii и Sp. mistacinus встречаются только на ночницах: водяной, усатой и Брандта - и не обнаружены на других видах рукокрылых. Присутствие этих видов на одних и тех же зверьках может служить основой для предположения наличия межвидовой конкуренции, поскольку они поселяются на одних и тех же участках тела животного. При возрастании конкуренции Sp. kolenatii может вытеснять $S p$. mistacinus с крыловой перепонки либо на тело хозяина, либо в окружающее пространство. Блоха Ischnopsillus sp. в этом смысле менее конкурентоспособна по сравнению со спинтурницидами.

Полученные нами результаты подтверждают взгляды Ю.С. Балашова [28]. Он считает, что роль внешней среды (среды 2) в структурировании сообществ может проявляться сезонностью паразитирования разных видов, а также колебаниями плотностей популяций паразитов из-за изменений микроклимата разных частей тела хозяина. На современном уровне наших знаний о структуре и функционировании паразитарных сообществ трудно оценить относительное значение всех этих факторов. Для разных семейств эктопаразитов, представляющих самостоятельные эволюционные линии, характерны разные пути освоения экологических ниш на теле хозяев и в их местообитаниях.

Устойчивость паразитарной системы обеспечивается сложным комплексом паразито-хозяинных взаимодействий на стадии питания [15; 4]. При высокой численности паразита не многие особи популяции хозяина могут выдержать клещевую инвазию и погибают вместе с эктопаразитами, которые составляют большую часть популяции вида (обратная связь). Однако в смешанных колониях рукокрылых постоянные паразиты, в частности спинтурнициды, имеют сходные экологические ниши и способны инвазировать другие виды хозяев. Такую картину мы наблюдаем, когда в сообществах на одном виде хозяина присутствуют по два и даже три вида рода Spinturnix. Такие явления еще более усложняют структуру сообществ и взаимодействие видов в них, но в процессе длительного существования этих сообществ вырабатываются определенные механизмы, стабилизирующие всю систему.

В сообществах эктопаразитов рукокрылых встречаются виды, которые связаны корреляционной зависимостью только с одним фактором (Spinturnix acuminatus, Sp. plecotinus, Leptotrombidium russicum), но обнаруживаются и виды, которые демонстрируют как умеренно-положительные, так и умеренно-отрицательные корреляционные зависимости не с одним фактором, а с несколькими. Например, $S p$. myoti, $S p$. kolenatii, M. heteromorphus и др. (табл. 2). Из таблицы видно, что в сообществах между видами возникают сложные взаимоотношения, и численности популяций каждого из них зависят от различных факторов среды. На наш взгляд, неодинаковое воздействие среды на паразитарные системы, формирующиеся в пещерах естественного происхождения, также обеспечивает устойчивость сообществ эктопаразитов рукокрылых в целом. 
Таблица 2 - Корреляционная зависимость некоторых видов эктопаразитов от факторов среды

\begin{tabular}{|c|l|r|r|r|r|}
\hline № & Вид паразита & $\begin{array}{r}\text { Фак- } \\
\text { тор 1 }\end{array}$ & $\begin{array}{r}\text { Фак- } \\
\text { тор 2 }\end{array}$ & $\begin{array}{r}\text { Фак- } \\
\text { тор 3 }\end{array}$ & $\begin{array}{c}\text { Фак- } \\
\text { тор 4 }\end{array}$ \\
\hline 1 & Sp. myoti & 0,40 & 0,50 & 0,50 & $-0,60$ \\
\hline 2 & Sp. kolenatii & $-0,18$ & 0,80 & $-0,60$ & 0,06 \\
\hline 3 & $\begin{array}{l}\text { Macronyssus } \\
\text { heteromorphus }\end{array}$ & 0,60 & $-0,50$ & 0,10 & $-0,50$ \\
\hline 4 & $\begin{array}{l}\text { Myatrombicula } \\
\text { sp. }\end{array}$ & 0,75 & 0,13 & 0,40 & 0,40 \\
\hline 5 & $\begin{array}{l}\text { Ischnopsillus } \\
\text { obscurus }\end{array}$ & 0,30 & $-0,10$ & $-0,80$ & $-0,70$ \\
\hline 6 & $\begin{array}{l}\text { Steatonyssus } \\
\text { spinosus }\end{array}$ & $-0,25$ & 0,70 & 0,70 & 0,04 \\
\hline 7 & Sp. mystacinus & 0,20 & 0,20 & 0,96 & 0,10 \\
\hline 8 & $\begin{array}{l}\text { Ischnopsillus } \\
\text { hexactenus }\end{array}$ & 0,30 & $-0,10$ & 0,80 & $-0,20$ \\
\hline
\end{tabular}

\section{Заключение}

Сообщества эктопаразитов рукокрылых характеризуются определенной устойчивостью. Поскольку методы непараметрической статистики не обнаружили достоверных различий по хозяевам, годам и биотопам, то колонию рукокрылых и их эктопаразитов можно оценивать как единую сложно организованную систему, длительно существующую в пространстве и времени. В этой системе установились такие взаимосвязи, которые обусловливают успешное существование всех видов без выраженной конкуренции. На паразитарные сообщества оказывают влияние четыре главных фактора, из них первые два определяют примерно 65\% дисперсии. Каждый вид имеет свою позицию в факторном пространстве, их позиции не перекрываются. Их пространственное размещение указывает на то, что факторы, влияющие на системы, в процессе их эволюции не только сбалансировали численности популяций паразитов, но и каждый вид имеет свою нишу.

\section{Список литературы:}

1. Кеннеди К.Р. Экологическая паразитология. М.: Мир, 1978.230 с.

2. Гранович А.И. Паразитарные системы и структура популяций паразитических организмов // Паразитология, 1996. Т. 30, вып. 4. С. 343-356.

3. Чайка С.Ю. Паразитизм - существование организмов в составе паразитарных систем // Паразитология. 1998. Т. 32, вып. 1. С. 3-10.

4. Фадеева Г.А. Экологические аспекты формирования и стабильности паразитарных систем на примере прыткой ящерицы: дис. ... канд. биол. наук. Нижний Новгород, 1999. 114 с.

5. Бреев К.А. Применение негативного биномиального распределения для изучения популяционной экологии паразитов. Л.: Наука, 1972. 70 с.

6. Бреев К.А. Об уровнях численности подкожных оводов (Diptera, Hypodermatidae) сельскохозяйственных животных // Паразитология. 1979. Т. 13, вып. 2. С. 93-102.

7. Бреев К.А., Минарж Я.К. Тип и параметры распределения личинок обыкновенного подкожного овода (Hypodermabovis) в стадах крупного рогатого скота в разных частях ареала // Паразитология. 1978. Т. 26, вып. 1. С. 31-36.

8. Бреев К.А., Минарж Я.К. О статистической характеристике хозяинно-паразитарных отношений обыкновенного подкожного овода крупного рогатого скота (Hypodermabovis) в разных частях ареала // Паразитология. 1979. Т. 13, вып. 2. С. 93-101.

9. Гранович А.И. Паразитарная система как отражение структуры популяции паразитов: концепция и термины // Труды Зоологического института. 2009. т. 313, вып. 3. С. 329-337.

10. Беляков В.Д. Общие закономерности функционирования паразитарных систем (механизмы саморегуляции) // Паразитология. 1986. Т. 20, вып. 4. C. 249-255.

11. Esch G.W., Fernandez J.C. A Functional Biology of Parasitism // Evolutionary Aspects. 1993. P. 231-267.

12. Сопрунов Ф.Ф. Молекулярные основы паразитизма. М.: Наука, 1987. 234 с.

13. Высоцкая С.О. Биоценотические отношения между эктопаразитами и обитателями их гнезд // Паразитол. сб. 1967. Т. 23. С. 19-60.

14. Назарова И.В., Борисова В.И. Эктопаразиты мелких млекопитающих в естественных и трансформированных экосистемах Среднего Поволжья. Горький, 1990. 427 с. (Рукопись депонирована в ВИНИТИ № 2928-890).

15. Балашов Ю.С. Значение идей В.Н. Беклемишева о паразитарных системах и жизненных схемах видов в развитии паразитологии // Паразитология. 1991. Т. 25, вып. 3. С. 185-195.

16. Фадеева Г.А., Врагов В.В. Формирование фаунистических комплексов кровососущих клещей микромаммалий лесов Нижегородской области // Вестник Нижегородского университета. 2009. № 3. C. $118-125$.

17. Балашов Ю.С. Паразито-хозяинные отношения членистоногих с наземными позвоночными. Л.: Наука, 1982. 320 с.

18. Балашов Ю.С. Видовое разнообразие паразитарных сообществ насекомых и клещей на млекопитающих // Энтомологическое обозрение. 2002. Т. 81, № 4. C. 930-943.

19. Балашов Ю.С. Паразитизм клещей и насекомых на наземных позвоночных. СПб.: Наука, 2009. 357 с.

20. Балашов Ю.С. Видовое разнообразие паразитарных сообществ насекомых и клещей на птицах // Энтомологическое обозрение. 2003. Т. 82, № 4. C. 922-942.

21. Stanyukovich M. Keys to the gamasid mites (Acari, Parasitiformes, Mesostigmata, Macronyssoidea et Laelaptidae) parasitizing bats (Mammalia, Chiroptera) from Russia and adjacent countries // Rudolstädter nat. hist. Schr. 7, 1997. P. 13-46.

22. Пинчук Л.М. Клещи рода Steatonyssus (Parasitiformes, Macronyssidae) от летучих мышей Молдавии // Паразиты животных и растений. Вып. 7. Кишинев: АН Молдавской ССР, 1971. С. 110-115.

23. Пинчук Л.М. Паразитические клещи семейства Spinturnycidae (Parasitiformes, Gamasoidea) от летучих мышей Молдавии // Паразиты животных и растений. Вып. 7. Кишинев: Академия наук Молдавской ССР, 1971. С. 93-110.

24. Кудряшова Н.И. Клещи краснотелки (Acariformes, Trombiculidae) Восточной Палеарктики. М.: KMK Scientific Press., 1998. 342 c.

25. Определитель насекомых Европейской части СССР. Т. 5. Ч. 2. Двукрылые, блохи. Л.: Наука, 1970. $943 \mathrm{c}$ 
26. Трухачева Н.В. Математическая статистика в медико-биологических исследованиях с применением пакета Statistica. М.: ГЭОТАР-Медиа, 2012. 384 с.

27. Фадеева Г.А., Борякова Е.Е. Эктопаразиты рукокрылых - обитателей карстовых пещер памятника природы «Ичалковский бор» (Нижегородская область) // Самарский научный вестник. 2018. Т. 7, № 4 (25). С. $122-126$.

28. Балашов Ю.С. Экологические ниши эктопаразитов // Паразитология. 2005. Т. 39, вып. 6. С. 441-455.

\title{
ASSESSMENT OF THE STABILITY OF BAT ECTOPARASITE COMMUNITIES USING A PRINCIPAL COMPONENT ANALYSIS (PCA) METHOD
}

(C) 2019

Fadeeva Galina Anatolievna, candidate of biological sciences, associate professor of Botany and Zoology Department

Boryakova Elena Evgenievna, candidate of biological sciences, associate professor of Botany and Zoology Department

National Research Lobachevsky State University of Nizhny Novgorod (Nizhny Novgorod, Russian Federation)

\begin{abstract}
The paper deals with a research of epiparasite communities in native karst caves in the South of Nizhny Novgorod Region. Six species of bats such as Daubenton's water bat, Brandt's bat, whiskered bat, pond bat, northern bat and long-eared bat were examined. A Principal Component Analysis was used to identify factors influencing the composition of ectoparasites as well as the number and distribution of mites in mixed colonies of bats. As the cave and its inhabitants can be considered as a microbiotope, it is obvious that there are specific relations between inhabitants in caves. Special habitat conditions indirectly influence the parasitic systems developing there which are characterized by certain stability. Mann-Whitney U-test was used to estimate the difference between samples of animals from different habitats. Methods of nonparametric statistics didn't find significant distinctions by the hosts, years and biotopes, the bat colony and their ectoparasites can be estimated as a single complexly organized system, existing long in space and time. From all possible factorial space four factors have significant effect on systems. The contribution of the first and second factors is equal to $65 \%$ of variance (specificity of parasites to hosts and a factor of dominant species presence). In parasite communities of bats interrelations which cause successful existence of all types without the expressed competition are observed. Our results indicate a complex relationship between the parasites in the community on the one hand, and long-term existence of the community on the other hand. Each member of parasitic system has a position in factorial space. In parasite communities of bats we met only one factordependent species (Spinturnix acuminatus, Sp. plecotinus, Leptotrombidium russicum). Species that show moderate and positive, moderate and negative correlation dependence with several factors are found. For example, Spinturnix myoti, Sp. kolenatii, Macronyssus heteromorphus, etc. Heterogeneity of environmental impact on the parasitic systems which are formed in natural caves provides stability of bat parasite communities in general.

Keywords: parasitic system; bats; bat ectoparasites; karst caves; Nizhny Novgorod Region; Volga Upland; gamasinae; spinturnicidae; nycterebiidae; Principal Component Analysis; stability of communities; parasite communities; specificity of parasites to hosts.
\end{abstract}

УДК $57.033 ; 631.95$

DOI 10.24411/2309-4370-2019-11122

Статья поступила в редакцию 05.01.2019

\section{ВЛИЯНИЕ ПОСЛЕДЕЙСТВИЯ РАЗЛИЧНЫХ СИСТЕМ УДОБРЕНИЙ НА МИКРОЭЛЕМЕНТНЫЙ СОСТАВ ПОЧВЫ И ЗЕРНА ОЗИМОЙ ПШЕНИЦЫ В УСЛОВИЯХ ПРИМОРСКОГО КРАЯ}

(C) 2019

\author{
Фадякина Ирина Сергеевна, инженер-химик лаборатории агрохимических анализов \\ Федеральный научный изентр агробиотехнологий Дальнего Востока им. А.К. Чайки \\ (n. Тимирязевский, г. Уссурийск, Приморский край, Российская Федерация)
}

\footnotetext{
Аннотация. В данной статье представлено влияние последействия минеральных, органических и известковых удобрений на агрохимические и экологические показатели лугово-бурой отбеленной почвы Приморского края. Рассматривается накопление микроэлементов зерном озимой пшеницы по вариантам опыта. Полевые опыты проведены в 2011-2014 гг. в севообороте агрохимического стационара ФГБНУ «Федеральный научный центр агробиотехнологий Дальнего Востока им. А.К. Чайки». Содержание микроэлементов в почве и зерне определяли на атомном адсорбционном спектрофотометре Shimadzu AA-6200. Согласно результатам наших исследований выявлено, что последействие разных систем удобрений повлияло на содержание ряда валовых и подвижных форм микроэлементов в исследуемой почве. Установлено, что почва не препятствует накоплению в ней подвижных форм никеля, свинца, кадмия, цинка, меди и кобальта. Способность противостоять загрязнению пищевой цепи (барьер системы), то есть проявление защитных механизмов зерна, от никеля, меди и кобальта изменяется слабо по вариантам опыта. Для свинца, кадмия и цинка барьер системы находится в средней степени рассеивания данных по вариантам опыта, проявляя более эффективные защитные возможности на варианте с последействием известково-органоминеральной системы удобрений, где содержание последних достигает максимальных значений.
} 